\title{
KONSERVASI MATAAIR SEBAGAI UPAYA MANAJEMEN SUMBERDAYA AIRTANAH BERKELANJUTAN (STUDI KASUS: MATAAIR LINGSENG, SUB DAS CELENG, KABUPATEN BANTUL, YOGYAKARTA)
}

\author{
Ira Mughni Pratiwi \\ Program Studi Teknik Lingkungan, Fakultas Teknologi Mineral, \\ Universitas Pembangunan Nasional "Veteran" Yogyakarta \\ mughniira@gmail.com
}

\begin{abstract}
Intisari - Mataair merupakan salah satu sumberdaya air yang berasal dari airtanah. Mataair mempunyai peran penting sebagai pemasok kebutuhan air di berbagai tempat. Mataair telah menjadi bagian penting manusia dalam aspek sosial, budaya, dan ekonomi. Meskipun debit saat musim kemarau lebih kecil dibandingkan dengan saat musim penghujan tetapi dapat memenuhi kebutuhan masyarakat sepanjang tahun. Penelitian ini bertujuan untuk mengetahui tingkat kerentanan mataair dan konservasi mataair sebagai manajemne sumberdaya air berkelanjutan.

Metode yang digunakan adalah metode survei, pemetaan, dan skoring. Parameter yang dinilai untuk menentukan tingkat kerentanan mataair adalah curah hujan, kemiringan lereng, konduktivitas hidraulika, infiltrasi, debit mataair, dan penggunaan lahan.

Mataair Lingseng merupakan mataair yang muncul melalui rekahan breksi dengan debit berfluktuatif. Debit rerata di bulan Oktober 113,33 ml/dt; bulan Desember 183,33 ml/dt; bulan April 91,67 ml/dt; dan bulan Mei $54 \mathrm{ml} / \mathrm{dt}$. Tingkat kerentanan degradasi Mataair Lingseng mempunyai skor 18 dan termasuk dalam kelas III dengan kriteria kerentanan menengah. Konservasi dengan hutan pertanian sistem multistrata agrosilvikultur. Tanaman yang digunakan adalah pohon sengon, pohon kakao/coklat, pohon lamtoro, tanaman jagung, dan mulsa organik serta mulsa batu.
\end{abstract}

Kata kunci: Konservasi, Kerentanan, Mataair, Berkelanjutan

I. Pendahuluan

\subsection{Latar Belakang}

Air merupakan salah satu kebutuhan makhluk hidup di dunia yang paling utama. Kebutuhan air akan semakin meningkat seiring dengan kemajuan teknologi yang berdampak kepada berkembangnya kebutuhan manusia. Air terdapat di permukaan ataupun di bawah permukaan (airtanah). Suripin (2009) mengungkapkan bahwa airtanah merupakan sumber air tawar terbesar di planet bumi, mencakup kira-kira 30\% dari total air tawar atau 10,5 juta $\mathrm{km}^{3}$. Berdasarkan dari pernyataan diatas, van der Weert (1994) memperkirakan aspek utama yang menentukan peningkatan permintaan air di masa depan adalah jumlah populasi. Populasi dalam periode 1990 2015 diperkirakan meningkat sebesar 39\% dari 179 juta pada tahun 1990 menjadi 249 juta pada tahun 2015. Kekeringan, banjir, polusi air, dan konflik regional mengenai sumberdaya air terjadi di berbagai penjuru dunia (Prinz, 2005 dalam Brontowiyono, 2008).

Mataair merupakan salah satu sumberdaya air yang berasal dari airtanah. Mataair mempunyai peran penting sebagai pemasok kebutuhan air di berbagai tempat. Menurut Moore (2002) mataair adalah sumber utama dari informasi hidrogeologi. Sebuah mataair adalah aliran airtanah secara alami pada permukaan tanah. Mataair telah menjadi bagian penting manusia dalam aspek sosial, budaya, dan ekonomi. Mataair telah menjadi sumber air yang penting untuk manusia. 
Mataair Lingseng adalah salah satu mataair yang terdapat di Sub-DAS Celeng, Kabupaten Bantul, D.I.Yogyakarta. Mataair Lingseng digunakan oleh masyarakat sekitar untuk memenuhi kebutuhan hidupnya sepanjang tahun, meskipun debit mataair tersebut pada saat musim kemarau mengalami penurunan dibandingkan dengan saat musim penghujan. Oleh karena itu, ketergantungan masyarakat akan keberadaan dan pemanfaatan mataair tersebut harus diimbangi dengan pengelolaan lingkungan yang baik. Selain itu dengan pertimbangan isu penurunan muka airtanah di Yogyakarta yang menyatakan bahwasannya sejak tahun 2000 permukaan airtanah di Yogyakarta turun $\pm 30 \mathrm{~cm}$ per tahun karena perubahan iklim (Hendrayana, 2009 dalam Wahyuni, 2009). Pengelolaan lingkungan dimaksud sebagai upaya pelestarian keberadaan dan fungsi mataair untuk memenuhi kebutuhan masyarakat setempat waktu sekarang dan yang akan datang. Berdasarkan uraian tersebut penulis tertarik untuk melakukan penelitian tentang konservasi mataair di Sub-DAS Celeng Kabupaten Bantul D.I. Yogyakarta (Studi Kasus : Mataair Lingseng, Sub-DAS Celeng, Kabupaten Bantul, D.I. Yogyakarta.

\subsection{Tujuan}

1) Mengetahui tingkat kerentanan mataair di daerah penelitian.

2) Menentukan arahan konservasi mataair sebagai manajemen sumberdaya airtanah berkelanjutan.

\section{Metode}

Metode yang digunakan adalah metode survei, pemetaan, dan skoring. Survei lapangan dilakukan untuk mendukung pemetaan, wawancara, pengukuran volume penggunaan air oleh masyarakat, dan untuk memperoleh data terhadap kegiatan yang dilakukan di lapangan dengan cara melakukan pengamatan, pengukuran di lapangan, dan mencatat hal-hal yang penting dan mengenai yang berhubungan dengan hasil penelitian yang dilakukan. Metode skoring atau pengharkatan adalah teknik analisis data kuantitatif yang digunakan untuk memberikan nilai pada masing-masing karakteristik dari sub-sub variabel agar dapat dihitung nilainya serta dapat ditentukan peringkatnya (Sys dkk., 1991). Parameter yang dinilai untuk menentukan tingkat kerentanan mataair adalah sebagai berikut :

\begin{tabular}{|c|c|c|}
\hline No. & $\begin{array}{l}\text { Kintcria Terdapatuya } \\
\text { MTatair } \\
\text { Iflin }\end{array}$ & $\begin{array}{l}\text { Parameter yang } \\
\text { Dihutuhian } \\
\text { Curah huga }\end{array}$ \\
\hline \multirow{3}{*}{$\begin{array}{l}2 . \\
3 .\end{array}$} & \multirow{3}{*}{$\begin{array}{l}\text { Reisef } \\
\text { Tanali }\end{array}$} & Kemiringin lereng \\
\hline & & a. Telstur tanali \\
\hline & & b. Infilorasi \\
\hline \multirow[t]{2}{*}{4} & \multirow[t]{2}{*}{ Razian } & $\begin{array}{l}\text { a Jrnis hatian } \\
\text { b. Kectudukan batuan }\end{array}$ \\
\hline & & 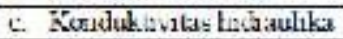 \\
\hline 5 & Kondisi hidrolngi & Tehit matarir \\
\hline 0. & Per & Pengansan lakan \\
\hline
\end{tabular}


III. Hasil dan Pembahasan

Evaluasi adalah proses penilaian meliputi evaluasi parameter dan evaluasi tingkat kerentanan degradasi mataair. Evaluasi parameter dibedakan menjadi dua yaitu evaluasi kuantitatif dan kualitatif. Evaluasi kuantitatif meliputi evaluasi parameter geofisik lingkungan. Sedangkan, evaluasi kualitatif mencakup evaluasi sosial, ekonomi, dan budaya masyarakat. Evaluasi tingkat kerentanan degradasi mataair dilakukan terhadap nilai masing-masing parameter sehingga diperoleh kelas kerentanan, dan kelas kerentanan tersebut kemudian dievaluasi untuk suatu arahan pengelolaan agar mataair dapat terjaga ketersediaan airnya.

\subsection{Curah Hujan}

Menurut Kodoatie, 1996, Curah hujan merupakan masukan bagi airtanah, sehingga tinggi dan rendahnya curah hujan mempengaruhi debit atau ketersediaan airtanah/mataair. Daerah penelitian mempunyai tipe iklim agak kering dengan curah hujan rerata harian $41-80 \mathrm{~mm} / \mathrm{hari}$ dan curah hujan rerata tahunan 1500-2000 mm/tahun. Berdasarkan tabel skoring curah hujan (Wismarini, 2011), Intensitas kepentingan curah hujan termasuk pada derajat nilai sedang dengan skor 3.

Data curah hujan $(\mathrm{CH})$ diperoleh dari stasiun pemantau terdekat yaitu Stasiun Dlingo 20052011. Grafik curah hujan disajikan pada Gambar 1. Berdasarkan grafik curah hujan rerata maka, antara bulan Juni-Agustus debit mataair akan relatif kecil dan debit relatif besar antara bulan November-Februari. Curah hujan rerata tertinggi di stasiun meteorologi Dlingo pada bulan Februari yaitu $405 \mathrm{~mm}$ dan curah hujan rerata terendah pada bulan Agustus yaitu 29,71 mm..

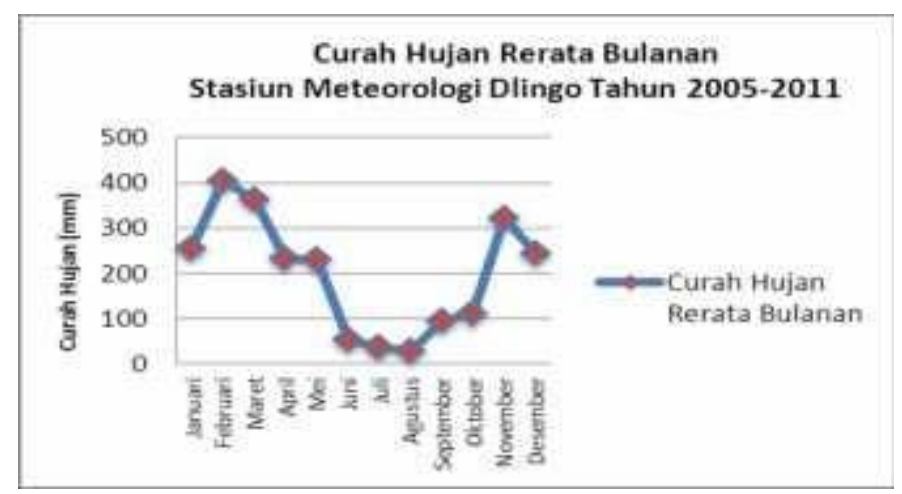

Gambar 1 Grafik Curah Hujan Rerata Bulanan Stasiun Terdekat

Intensitas curah hujan sedang dan tidak diimbangi dengan tingkat infiltrasi yang besar mempengaruhi ketersediaan jumlah airtanah. Menurut Setiadi dan Tjondronegoro (1989) nilai evapotranspirasi bukan hanya dipengaruhi oleh tutupan vegetasi. Kecepatan potensi evapotranspirasi juga ditentukan oleh suhu udara, kecepatan angin, kelembaban dan radiasi serta jenis tutupan vegetasi. Intensitas curah hujan yang relatif kecil memberikan dampak terhadap potensi kerentanan degradasi kuantitas airtanah dan indikasi terlihat dari debit mataair yang 
berfluktuatif dan relatif kecil. Besarnya tingkat evapotranspirasi karena ketidaksesuaian jenis tutupan vegetasi yang ditanam meningkatkan potensi degradasi airtanah.

\subsection{Kemiringan Lereng}

Kemiringan lereng didaerah penelitian mempunyai derajat kepentingan nilai curam (1420\%) dengan skor 2 (van Zuidam dan van Zuidam-Cancelado, 1979). Kemiringan lereng pada suatu daerah akan mempengaruhi laju air limpasan dan laju infiltrasi. Kemiringan lereng curam akan mempercepat laju air limpasan dan mengurangi air yang masuk ke dalam tanah. Laju air masuk ke dalam tanah berpengaruh terhadap debit mataair yang fluktuatif. Debit air yang berfluktuatif berpengaruh terhadap potensi degradasi sehingga diperlukan konservasi untuk meningkatkan laju infiltrasi.

Daerah penelitian berdasarkan zona fisiografi terletak di Zona Pegunungan Selatan (Bemmelen, 1949) dan Sub Zona Baturagung (Harsolumekso dkk., 1997 dalam Bronto dkk, 2001). Berdasarkan morfologinya daerah penelitian merupakan bagian timur dari cekungan Bantul (Langgeng dan Tjahyo, 2006 dalam Daryono, 2011) dengan dinding patahan perbukitan Baturagung (Karnawati, dkk., 2006), ilustrasi disajikan pada Gambar 2. Berdasarakan peta topografi, hasil survei, dan pemetaan bentuklahan daerah penelitian termasuk bentuklahan asal denudasional dengan satuan bentuklahan perbukitan denudasional.

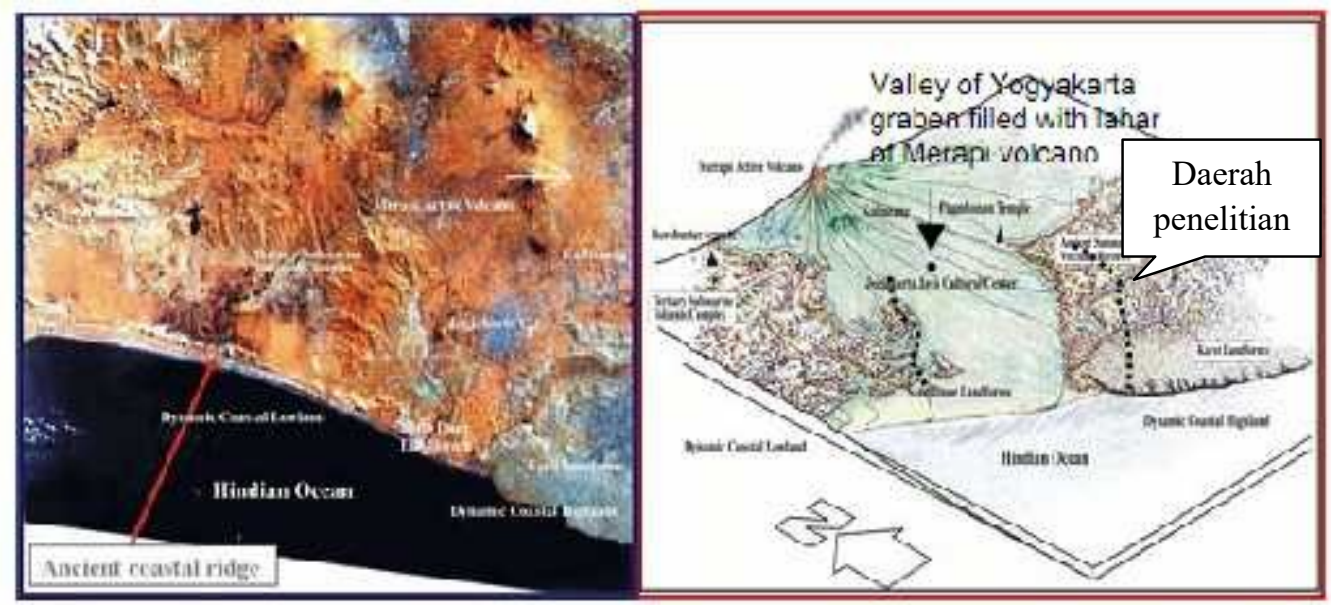

Sumber: Karnawati dkk., 2006

Gambar 2 Citra Landsat dan Kondisi Fisiografi Kota Yogyakarta dan Sekitarnya

Satuan bentuklahan perbukitan denudasional menempati Formasi Nglanggeran dan Formasi Semilir. Proses geomorfologi yang sedang berlangsung adalah erosi tanah, dan gerakan batuan dengan tipe jatuhan dan longsoran. Perbukitan denudasional mempunyai topografi berbukit dan bergelombang dengan kemiringan lereng antara landai-sangat curam dengan perbedaan tinggi relief antara 100 - 450 meter dengan terkikis sedang pada stadium muda. Lahan masih tinggi banyak dijumpai permukaan asli dengan dinding terjal. Tanah jauh di atas level dasar. Satuan batuan 
penyusun di daerah penelitian adalah satuan breksi dengan kedudukan kekar umum $\mathrm{N} 270^{\circ} \mathrm{E} / 27^{\circ}$,

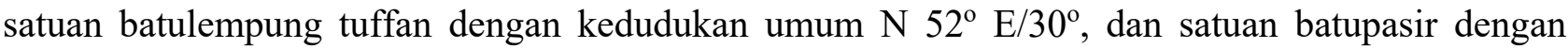
kedudukan umum $\mathrm{N} 51^{\circ} \mathrm{E} / 19^{\circ}$.

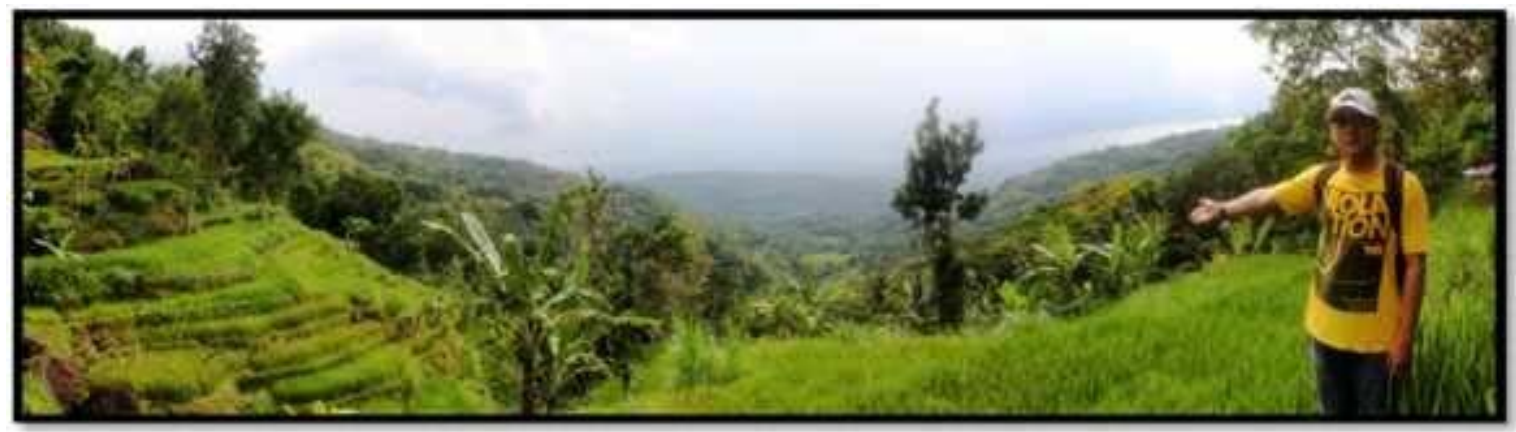

Gambar 3 Lembah Tempat Mengalirnya Air dari Mataair Lingseng (Foto Penulis Mei 2013, Kamera Menghadap Utara)

Keterdapatan airtanah tidak banyak dipengaruhi oleh kemiringan lereng. Akan tetapi, dalam pelestarian airtanah terhadap potensi degradasi kuantitas airtanah kemiringan lereng merupakan

faktor penting di dalam memilih teknik konservasi air. Kemiringan lereng berpengaruh dalam konservasi air karena semakin besar kemiringan lereng maka laju aliran permukaan makin cepat, dan daya kikis serta daya angkut air aliran permukaan makin kuat dan cepat. Oleh karena itu, strategi konservasi air pada lahan berlereng adalah tata cara dalam mengatur tanaman, untuk jenis tanaman daerah penelitian mempunyai spesies tanaman pionir yang dapat dimanfaatkan untuk konservasi. Berdasarkan keterangan di atas, pada arahan konservasi dalam penelitian ini, tata cara penanaman yang sesuai dengan kemiringan lereng akan lebih ditekankan. Teknik Penanaman pada lahan miring dapat memperlambat laju aliran permukaan dan mencegah terjadinya erosi sehingga memberikan kesempatan lebih lama agar air meresap ke dalam tanah.

\section{$3.3 \quad$ Infiltrasi}

Tanah di daerah penelitian mempunyai tektur liat yang bersifat kedap air dengan ukuran pori kecil karena tidak memungkinkan air keluar dengan cepat sehingga tanah tidak beraerasi dengan baik. Pori-pori kecil juga membuat udara tidak dapat keluar dari tanah dengan cepat sehingga air masuk ke dalam tanah dalam waktu yang lama. Tanah latosol merupakan tanah yang berkembang dengan solum masih mempunyai ciri yang sama dengan batuan induk. Batuan induk terletak di bawah lapisan solum yang bertekstur halus memperlambat gerak air ke bawah sebelum lapisan atas jenuh air.

Infiltrasi adalah fenomena meresapnya air hujan yang jatuh pada permukaan tanah. Kecepatan infiltrasi yang tinggi terjadi pada waktu permulaan hujan, terutama selama musim kemarau dan dengan penutup tumbuhan yang rapat (Danaryanto dkk., 2010). Infiltrasi dipengaruhi oleh ukuran pori, kemantapan pori, kandungan air, dan profil tanah (Arsyad, 1989). Laju infiltrasi di 
daerah penelitian memiliki nilai kurang dari $0,5 \mathrm{~cm} / \mathrm{jam}$. Laju infiltrasi tersebut termasuk kategori sangat kecil dengan tekstur tanah liat dan intensitas kepentingannya memiliki skor 5 (Arsyad, 1989).

Kapasitas infiltrasi tanah dapat ditingkatkan dengan memperbaiki struktur tanah (Arsyad, 1989). Secara umum cara efektif dalam peningkatakan kapasitas infiltrasi tanah atau menjaga kapasitas infiltrasi yang tinggi dengan memberikan penutupan terhadap tanah dengan tanaman penutup tanah atau mulsa, mulsa yang digunakan adalah mulsa organik.

Mulsa juga dapat dimanfaatkan untuk melindungi permukan tanah dari pukulan langsung butiran hujan sehingga mengurangi terjadinya erosi percik (splash erosion), selain mengurangi laju dan volume limpasan permukaan (Suwardjo, 1981 dalam Subagyono dkk., 2003). Bahan mulsa yang sudah melapuk akan menambah kandungan bahan organik tanah dan hara. Mulsa mampu menjaga stabilitas suhu tanah pada kondisi yang baik untuk aktivitas mikroorganisme. Relatif rendahnya evaporasi, berimplikasi pada stabilitas kelengasan tanah.

\subsection{Konduktivitas Hidraulika}

Konduktivitas hidraulika adalah kemampuan suatu lapisan batuan untuk melalukan air, berhubungan dengan bergeraknya air dalam batuan (Sudarmadji, 2013). Konduktivitas hidraulika di daerah penelitian merupakan bagian dari akuifer (bercelah atau sarang) produktif kecil dengan airtanah langka terdiri dari akuifer produktif kecil setempat, keterusan sangat rendah. Akuifer produktif kecil menutupi akuifer produktif dengan penyebaran luas, akuifer dengan keterusan tinggi ditutupi oleh endapan bersifat lempungan, debit air kurang dari 10 liter/detik. Dalam klasifikasi Todd (1980) termasuk dalam material kerikil kasar dengan derajat nilai $150 \mathrm{~m} / \mathrm{hari}$ dan intensitas kepentingan skor 1. Besar nilai konduktivitas hidraulika dipengaruhi oleh porositas dan sifat fisik air (densitas dan viskositas). Nilai konduktivitas hidraulika batuan tidak dapat ditingkatkan karena nilainya bersifat mutlak terjadi akibat faktor alam.

\subsection{Debit Mataair}

Debit mataair di daerah penelitian termasuk dalam kelas sangat kecil yaitu kurang dari 10 1/d dengan intensitas kepentingan skor 5 (Meinzer, 1923; dalam Todd, 1980). Mataair di daerah penelitian muncul melalui rekahan dan daerah perpotongan lereng (Gambar 4). Rembesan mataair keluar melalui rekahan breksi (Gambar 5). Hal ini diketahui melalui penampang/ profil satuan batuan yang menunjukkan hubungan keselarasan antara satuan batulempung tuffan, satuan batupasir, dan satuan breksi. Batulempung sebagai batuan dasar impermeabel yang berfungsi sebagai penahan air sehingga tidak lolos ke bawah. Sedangkan batupasir sebagai batuan permeabel yang mampu menyimpan air dan meloloskan air. Kekar-kekar pada pemunculan mataair mempunyai strike dip sesuai dengan arah aliran air dengan kekar umum $\mathrm{N} 270^{\circ} \mathrm{E} / 27^{\circ}$. 


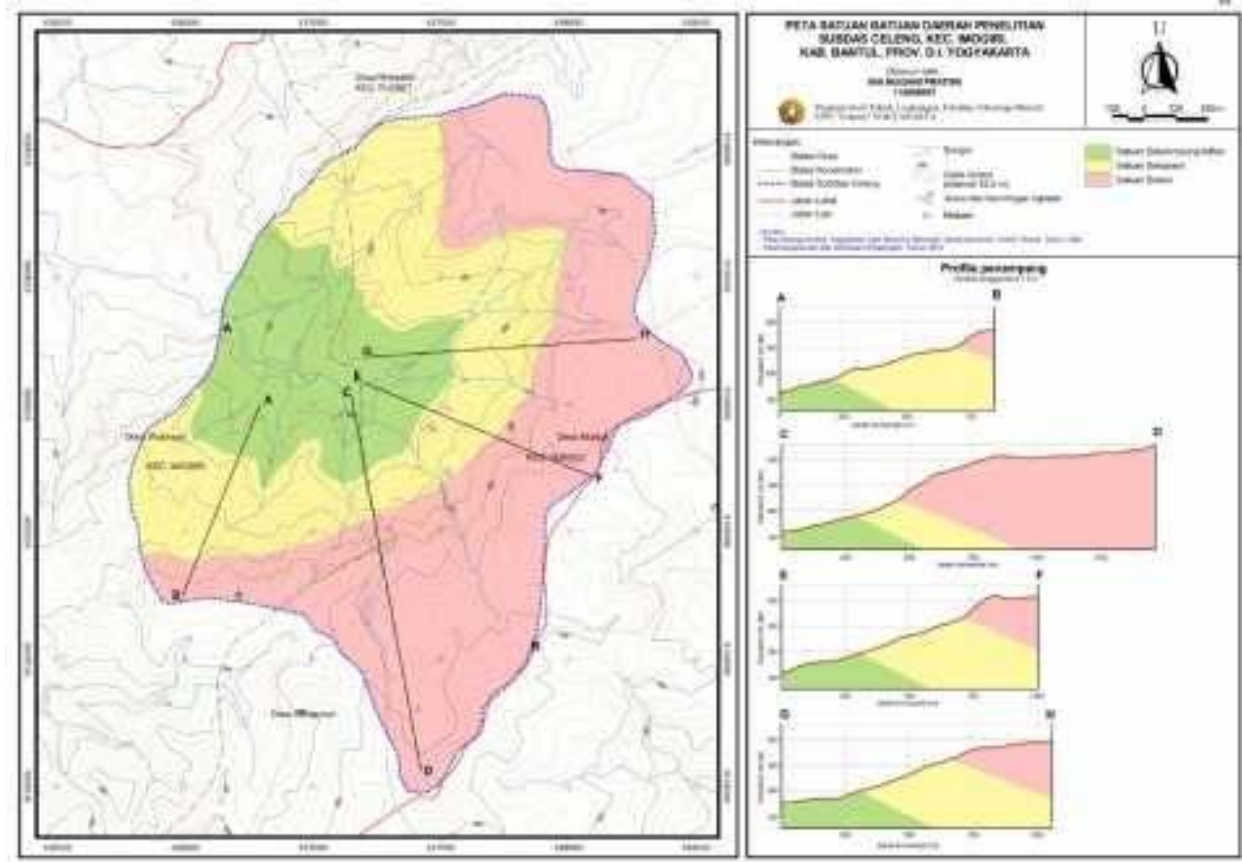

Sumber: Survei Lapangan, 2013

Gambar 4 Peta Satuan Batuan

Debit mataair dikontrol oleh curah hujan, kemiringan lereng, konduktivitas hidraulika, laju infiltrasi, dan penggunaan lahan. Untuk mengetahui keterkaitan masing-masing parameter terhadap kuantitas debit mataair, maka dilakukan pengukuran debit mataair. Pengukuran debit Mataair Lingseng dilakukan saat musim penghujan, kemarau, dan pancaroba. Pengukuran dilakukan pada bulan Oktober dan Desember tahun 2012 serta bulan April dan Mei tahun 2013 disajikan pada Tabel 6 .
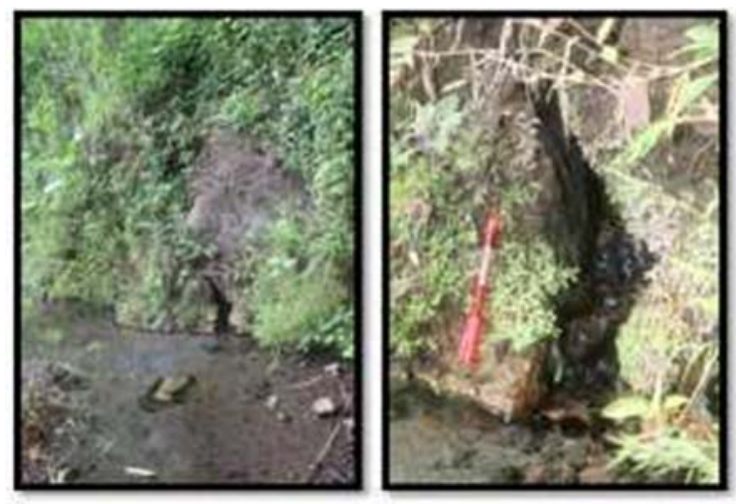

Foto Penulis Mei 2013, Kamera Menghadap ke Selatan

Gambar 5 Rembesan Keluar Melalui Rekahan Breksi di Daerah Hulu 
Tabel 6 Debit Rerata Mataair Lingseng

\begin{tabular}{|c|l|c|c|c|c|}
\hline \multirow{2}{*}{ NO } & \multirow{2}{*}{ BULAN } & \multicolumn{3}{|c|}{$\begin{array}{c}\text { PENGHITUNGAN DEBIT } \\
\text { (ml/dt) }\end{array}$} & \multirow{2}{*}{\begin{tabular}{c}
\multirow{2}{*}{ DEBIT } \\
\end{tabular}} \\
\cline { 3 - 5 } & & Pengukuran I & Pengukuran II & Pengukuran III & \\
\hline 1 & Oktober & 100 & 120 & 120 & 113.33 \\
\hline 2 & Desember & 150 & 200 & 200 & 183.33 \\
\hline 3 & April & 75 & 100 & 100 & 91.67 \\
\hline 4 & Mei & 66 & 46 & 50 & 54 \\
\hline
\end{tabular}

Sumber: Hasil Pengukuran Lapangan

\subsection{Penggunaan Lahan}

Kebutuhan pangan, sandang, dan papan mendorong intervensi manusia terhadap lingkungan, yakni membudidayakan sumberdaya alam yang ada pada lingkungan. Intervensi tersebut akan mengubah tata guna lahan, untuk memungkinkan pembangunan pemukiman, daerah industri, perluasan kawasan urban, pembangunan infrastruktur, kawasan pariwisata, dll. Menurut Soetrisno (2000) akan mengakibatkan jumlah dan kecepatan infiltrasi berkurang dan menurunkan jumlah airtanah karena imbuhan berkurang.

Pengaruh aktivitas manusia berpengaruh kecil terhadap siklus hidrologi tetapi mempunyai pengaruh yang besar terhadap proses hidrologi (Sudarmadji, 2013). Apabila tutupan vegetasi berkurang atau hilang maka proses intersepsi akan berkurang atau tidak akan terjadi proses intersepsi. Proses peresapan air ke dalam tanah akan berkurang. Intensitas kepentingan semak belukar adalah skor 2 (Wismarini, dkk, 2011) dengan derajat kepentingan infiltrasi besar. Nilai infiltrasi yang kecil di daerah penelitian lebih dikontrol oleh jenis dan tekstur tanah. Penutup lahan di daerah resapan adalah vegetasi dengan tingkat kerapatan rapat akan tetapi hal tersebut membuat nilai evapotranspirasi lebih besar daripada infiltrasi. Nilai evapotranspirasi yang relatif besar karena faktor pemanfaatan hutan sebagai penutup lahan dan jenis vegetasi.

\section{Tingkat Kerentanan dan Arahan Konservasi Mataair Lingseng}

Evaluasi tingkat kerentanan degradasi mataair diperoleh melalui analisis menggunakan cara pengharkatan pada masing-masing parameter. Setiap parameter yang diteliti diberi nilai yaitu menggunakan angka $1-5$. Parameter yang lebih besar rentan terdegradasi memiliki nilai yang lebih besar dibandingkan dengan parameter yang tidak memicu terjadinya degradasi mataair. Skor diperoleh dari penjumlahan masing-masing parameter. Tingkat kerentanan degradasi Mataair Lingseng termasuk dalam kelas kerentanan III kriteria kerentanan menengah dengan skor 18.

Berdasarkan parameter yang digunakan sebagai ukuran potensi kerentanan degradasi kuantitas mataair menunjukkan bahwa debit mataair relatif kecil. Curah hujan yang besar tanpa diimbangi dengan laju infiltrasi yang tinggi hanya akan menjadi air limpasan tidak memberi imbuhan airtanah. Kemiringan lereng curam membuat pengaliran air secara gravitasi memudahkan 
akses masyarakat terhadap air mataair. Akan tetapi, kemiringan lereng yang curam di daerah resapan membuat laju air limpasan lebih besar dibandingkan dengan laju air masuk ke dalam. Tekstur tanah yang liat membuat proses infiltrasi menjadi lebih lambat.

Kontrol alam terhadap keterdapatan airtanah dan debit air ditunjukkan dengan keterdapatan mataair pada batuan berumur tua dengan proses pemadatan mengakibatkan pori-pori lebih kecil berakibat terhadap tingkat kelulusan air yang kecil. Rekahan sekunder pada batuan kemunculan mataair tidak berpengaruh besar terhadap debit mataair karena rekahan gabungan yang kecil. Penutup lahan dan penggunaan lahan di daerah resapan airtanah telah sesuai yaitu bervegetasi. Akan tetapi, belum tepat karena hanya dibiarkan tumbuh dengan tumbuhan heterogen semak belukar. Infiltrasi yang terjadi belum secara maksimal. Debit mataair yang relatif kecil tidak diimbangi dengan pengelolaan yang baik dalam pendistribusiannya sehingga tidak maksimal.

Arahan konservasi sebagai manajemen sumberdaya airtanah berkelanjutan yang diterapkan sesuai dengan tingkat potensi kerentanan degradasi mataair adalah metode vegetatif. Tujuan konservasi vegetatif adalah untuk menambah besarnya cadangan air tanah yang dilakukan pada musim hujan yang kemudian dimanfaatkan pada musim kemarau, mengurangi beban saluran drainase karena volume genangan air berkurang serta dapat menambah debit aliran dasar dan mata air yang merupakan sumber utama aliran mantap. Teknik konservasi tanah dan air secara vegetatif dalam bentuk pengelolaan tanaman berupa pohon yaitu tanaman tahunan maupun tanaman setahun dipadukan dengan tindakan konservasi tanah dan air secara pengelolaan.

Daerah penelitian memiliki kemiringan lereng curam antara 14\% - 20\% maka digunakan sistem multistrata agrosilvikultur. Agrosilvikultur merupakan Kombinasi antara komponen atau kegiatan kehutanan (pepohonan, perdu, palem, bambu, dll.) dengan komponen pertanian (Hairiah dkk, 2009 dalam Polontalo, 2009). Tanaman yang digunakan adalah tanaman tahunan dan semusim dengan perbandingan 50:50. Agrosilvikultur didukung juga dengan tanaman pelindung permukaan tanah yaitu mulsa. Multistrata dengan tanaman tajuk tinggi sebagai pelindung adalah pohon sengon, tanaman tajuk sedang sebagai tanaman tahunan adalah pohon kakao/coklat, dan tanaman musiman sebagai kombinasinya adalah jagung (Gambar 6). Selain penanaman multistrata, pohon yang digunakan adalah lamtoro yaitu dengan penggunaan di luar areal pertanaman utama dan merupakan sumber pupuk hijau dan mulsa serta untuk penghutanan dan perlindungan dinding jurang. Mulsa organik untuk melindungi permukaan tanah tanaman musiman dan mulsa batu digunakan sebagai pelindung permukaan tanah tanaman tahunan dan tanaman bertajuk tinggi. Mulsa terdiri dari bahan organik sisa tanaman (jerami padi, batang jagung, dan sisa tanaman lamtoro). Bahan tersebut disebarkan secara merata di atas permukaan tanah setebal $2-5 \mathrm{~cm}$ sehingga permukaan tanah tertutup sempurna. 


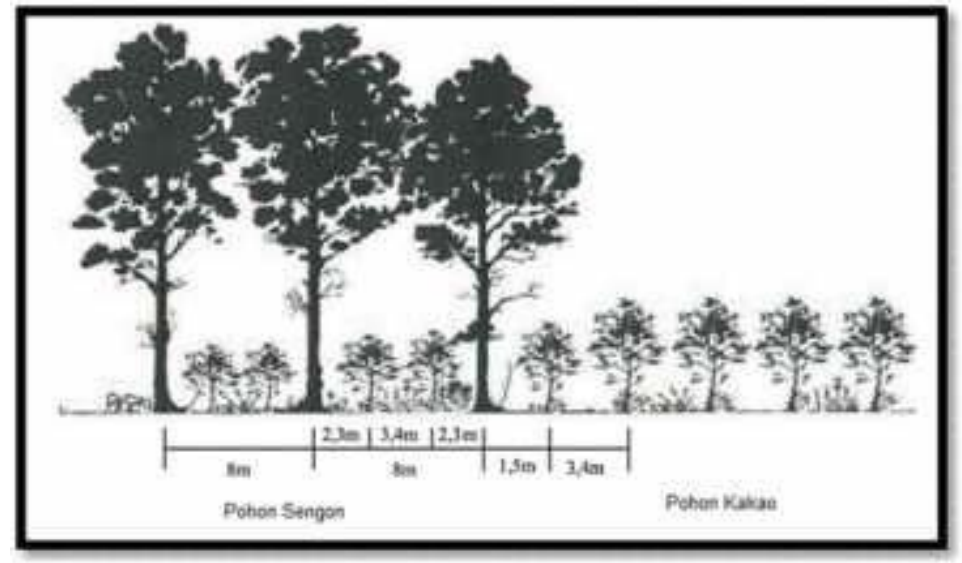

Sumber: Righi dkk., 2008

Gambar 6 Jarak Tanam Pohon Sengon dan Pohon Kakao

V. Kesimpulan dan Saran

1. Kesimpulan

Berdasarkan hasil penelitian Arahan Konservasi Mataair Berdasarkan Tingkat Kerentanan Mataair di Sub-Das Celeng Kabupaten Bantul D.I. Yogyakarta, maka dikemukan kesimpulan sebagai berikut:

a. Tingkat kerentanan degradasi Mataair Lingseng mempunyai skor 18 dan termasuk dalam kelas III dengan kriteria kerentanan menengah. Debit rerata di bulan Oktober 113,33 ml/dt; bulan Desember 183,33 ml/dt; bulan April 91,67 ml/dt; dan bulan Mei 54 ml/dt.

b. Arahan konservasi daerah penelitian adalah dengan hutan pertanian sistem multistrata agrosilvikultur. Tanaman yang digunakan adalah pohon sengon, pohon kakao/coklat, pohon lamtoro, tanaman jagung, dan mulsa organik serta mulsa batu. Jarak tanam antar pohon sengon adalah $8 \mathrm{~m}$; jarak tanam antar pohon kakao 3,4 m; dan pohon kakao/ coklat adalah $1,5 \mathrm{~m}$.

2. Saran

a. Konversi penutup lahan di daerah resapan air Mataair Lingseng dari semak belukar menjadi penggunaan lahan sebagai hutan konservasi.

b. Perlu adanya pengelolaan vegetasi penutup yang baik, dengan tetap menjaga dan melestarikan keberadaan kebun dan hutan. Dengan demikian, diharapkan dapat mengurangi jumlah air limpasan, dan akan meningkatkan jumlah resapan air kedalam tanah. 
Daftar Pustaka

,2009, Agroforestry, <http://bebasbanjir2025.wordpress.com/teknologi-pengendalianbanjir/agroforestry/> (diakses 26 Agustus 2013).

Arsyad, S., 1989, Konservasi Tanah dan Air, Bogor: Institut Pertanian Bogor.

Bemmelen, R. W. van, 1949, The Geology of Indonesia Vol. IA: General Geology of Indonesia and Adjacent Archipelagoes, The Hague: Martinus Nijhoff.

Bronto, S., Mulyaningsih, S., Hartono, G., Astuti, B., 2008, “Gunung Api Purba Watuadeg: Sumber Erupsi dan Posisi Stratigrafi”, Geologi Indonesia, Vol. 3 No. 3, hal. 117 - 128.

Brontowiyono, W., 2008, Sustainable Water Resources Management with Special Reference to Rainwater Harvesting - Case Study of KartaManTul, Java, Indonesia, Disertasi: Universität Fridericiana zu Karlsruhe (TH).

Danaryanto, Kodoatie, R. J., Hadipurwo, S., Sangkawati, S., 2010, Manajemen Airtanah Berbasis

Cekungan Airtanah, Pusat Lingkungan Geologi Badan Geologi Kementerian Energi dan Sumber Daya Mineral.

Daryono, 2011, Indeks Kerentanan Seismik Berdasarkan Mikrotremor pada setiap Satuan Bentuklahan Di Zona Graben Bantul, Yogyakarta, Disertasi: Universitas Gadjah Mada Yogyakarta

de Rider, N. A., 1972, Hydrogeology of Different Types of Plains, Wageningen: International Institute for Land reclamation and Improvement.

Deming, D., 2002, Introduction to Hydrogeology, New York: McGraw-Hill Companies.

FAO, World Reference Base for Soil Resources 2006, World Soil Resources Reports No. 103, Rome: FAO.

Handayani, W. dan Indrajaya, Y., 2011, "Analisis Hubungan Curah Hujan dan Debit Sub Sub Das Ngatabaru, Sulawesi Tengah”, Penelitian Hutan dan Konservasi Alam, Vol. 8, No. 2, hal. 143 153.

Karnawati, D., Pramumijoyo, S., Hendrayana, S., 2006, Geology of Yogyakarta, Java: The Dynamic Volcanic Arc City, Prosiding The $10^{\text {th }}$ IAEG International Congress, Nottingham United Kingdom, Engineering Geology for Tomorrow's Cities, London: The Geological Society of London.

Kodoatie, R. J., 1996, Pengantar Hidrogeologi, Yogyakarta: Andi.

Moore, J. E., 2002, Field Hydrogeology, Boca Raton: Lewis Publishers.

Polontalo, S., 2009, Pengolahan Tanah/ Penanaman menurut Kontur, $<$ http://bebasbanjir2025.wordpress.com/teknologi-pengendalian-banjir/pengolahantanahpenanaman-menurut-kontur/> (diakses 26 Agustus 2013). 
Purnama, S., 2010, Hidrologi Airtanah, Yogyakarta: Kanisius.

Righi, C.A., Pereira, A.M., Bernardes, S., Pereira C.R., Teramorto, E.R., dan Favarin, J.L., 2008, Coffee Water Use in Agroforestry System with Rubber Trees, $<$ http://www.scielo.br/scielo.php?script=sci arttext\&pid=S0100-67622008000500001 $>$ (diakses 26 Agustus 2013).

Saba, L. A., 2010, Karakteristik dan Potensi Mataair di Pulau Siompu Kabupaten Buton Provinsi Sulawesi Tenggara, Tesis: Universitas Gadjah Mada Yogyakarta.

Salamat, F., 2005, Evaluasi Potensi Mataair sebagai Sumber Air Bersih dan Upaya Pelestarian Lingkungan di Pulau Banggai Sulawesi Tengah, Tesis: Universitas Gadjah Mada Yogyakarta.

Santosa, L. W., 2006, “Kajian Hidrogeomorfologi Mataair di sebagian Lereng Barat Gunungapi Lawu", Forum Geografi, Vol. 20, No. 1, hal. 68 - 85.

Sarkol, R., 2010, Kajian Potensi Mataair sebagai Sumber Air Bersih di Pulau Wamar Kepulauan Aru Maluku. Tesis: Universitas Gadjah Mada Yogyakarta.

Setiadi, D. dan Tjondronegoro, P. D., 1989, Dasar-Dasar Ekologi, Pusat Antar Universitas Ilmu Hayat Institut Pertanian Bogor.

Soetoto, 1993, Geologi: Materi Penyusun Tubuh Bumi, Bakosurtanal.

Soetrisna, 2000, Interaksi Air Tanah dengan Lingkungan serta Permasalahan yang Timbul, $<$ http://www.geocities.ws/Eureka/Gold/1577/inter at ling.html $>$ (diakses 2 Mei 2013).

Strahler, A. N. dan Strahler, A. H., 1984, Elements of Physical Geography, $3^{\text {rd }}$ edition, New York: John Wiley and Sons.

Subagyono, K., Marwanto, S., Kurnia, U., 2003, Teknik Konservasi Tanah secara Vegetatif, Balai Penelitian Tanah Departemen Pertanian.

Sudarmadji, 2013, Mataair Perspektif Hidrologis dan Lingkungan, Sekolah Pascasarjana Universitas Gadjah Mada Yogyakarta.

Todd, D. K., 1980, Groundwater Hydrology, New York: John Wiley \& Sons. van Zuidam, R. A. dan van Zuidam-Cancelado, F. I., 1979, Terrain Analysis and Classification Using Aerial Photographs, Volume VII, AL Enschede: ITC.

Wahyuni, S., 2009. Yogyakarta Groundwater Surface Dropping $30 \mathrm{~cm}$ a Year. $<$ http://www.thejakartapost.com/news/2009/11/07/yogyakarta-groundwater-surface-dropping30cm-a-year.html> (diakses 22 Januari 2013).

Wismarini, D. Th., Handayani, D., dan Amin, F., 2011. "Metode Perkiraan Laju Aliran Puncak (Debit Air) sebagai Dasar Analisis Sistem Drainase di Daerah Aliran Sungai Wilayah Semarang Berbantuan SIG”, Teknologi Informasi DINAMIK Vol. 16, No.2, hal. 124 - 132. 